\title{
Polycaprolactone Foam Functionalized With Chitosan Microparticles - a Suitable Scaffold for Cartilage Regeneration
}

\author{
E. FILOVÁ ${ }^{1,2}$, B. JAKUBCOVÁ ${ }^{1,2}$, I. DANILOVÁ ${ }^{3}$, E. KUŽELOVÁ KOŠŤÁKOVÁ ${ }^{3}$, \\ T. JAROŠÍKOVÁ ${ }^{1}$, O. CHERNYAVSKIY ${ }^{4}$, J. HEJDA ${ }^{1}$, M. HANDL ${ }^{1}$, J. BEZNOSKA ${ }^{2}$, \\ A. NEČAS ${ }^{5}$, J. ROSINA ${ }^{1}$, E. AMLER ${ }^{1,2}$ \\ ${ }^{1}$ Faculty of Biomedical Engineering, Czech Technical University in Prague, Kladno, Czech \\ Republic, ${ }^{2}$ Institute of Experimental Medicine of the Czech Academy of Sciences, Prague, Czech \\ Republic, ${ }^{3}$ Technical University of Liberec, Liberec, Czech Republic, ${ }^{4}$ Institute of Physiology of the \\ Czech Academy of Sciences, Prague, Czech Republic, ${ }^{5}$ University of Veterinary and \\ Pharmaceutical Sciences, Brno, Czech Republic
}

Received January 22, 2015

Accepted July 10, 2015

On-line November 24, 2015

\begin{abstract}
Summary
For biodegradable porous scaffolds to have a potential application in cartilage regeneration, they should enable cell growth and differentiation and should have adequate mechanical properties. In this study, our aim was to prepare biocompatible scaffolds with improved biomechanical properties. To this end, we have developed foam scaffolds from poly- $\varepsilon$-caprolactone (PCL) with incorporated chitosan microparticles. The scaffolds were prepared by a salt leaching technique from either 10 or $15 \mathrm{wt} \%$ PCL solutions containing 0, 10 and $20 \mathrm{wt} \%$ chitosan microparticles, where the same amount and size of $\mathrm{NaCl}$ was used as a porogen in all the cases. PCL scaffolds without and with low amounts of chitosan (0 and 10 wt\% chitosan) showed higher DNA content than scaffolds with high amounts of chitosan during a 22-day experiment. 10 wt\% PCL with 10 and 20 wt\% chitosan showed significantly increased viscoelastic properties compared to 15 wt $\%$ PCL scaffolds with 0 and 10 wt $\%$ chitosan. Thus, $10 \mathrm{wt} \% \mathrm{PCL}$ scaffolds with $0 \mathrm{wt} \%$ and $10 \mathrm{wt} \%$ chitosan are potential scaffolds for cartilage regeneration.
\end{abstract}

\section{Key words}

Poly- $\varepsilon$-caprolactone $\bullet$ Chitosan $\bullet$ Cartilage regeneration $\bullet$ Foam • Microparticles

\section{Corresponding author}

E. Filová, Institute of Experimental Medicine of the Czech Academy of Sciences, Vídeňská 1083, Prague, Czech Republic. Phone/Fax: +420 296442 387. E-mail: evafil@biomed.cas.cz

\section{Introduction}

Scaffolds used in the tissue engineering of cartilage need to be non-immunogenic, biodegradable, biocompatible and should provide a cell-suitable environment for adhesion, proliferation and stimulation of proper cell differentiation. Their micro/nano-structure, which mimics the nature of the extracellular matrix, is important for cell proliferation and differentiation. Porous scaffolds with interconnected pores and higher porosity allow good cell proliferation and provide a suitable three-dimensional environment for chondrogenic differentiation of chondrocytes by greater cell-cell interactions. Moreover, scaffolds should possess suitable biomechanical properties to enable the implant and for the cells to withstand high mechanical loading in the body.

Biodegradable scaffolds, such as poly- $\varepsilon$ caprolactone (PCL) and chitosan have already proved their biocompatibility in tissue engineering for orthopaedic applications (Puppi et al. 2010, Sheehy et al. 2015, Hao et al. 2010, Saito et al. 2015, Jeong et al. 2012, Di Martino et al. 2005). Chitosan is a linear polysaccharide prepared by the deacetylation of chitin, composed of glucosamine and $\mathrm{N}$-acetyl glucosamine linked by $\beta$ 1-4 glycosidic bonds. It is structurally similar to glycosaminoglycans. The rate of chitosan degradation 
is inversely related to the degree of deacetylation. Moreover, chitosan is reported to possess antimicrobial properties (Di Martino et al. 2005).

Synthetic polymers, such as polycaprolactone, polylactic acid, polyglycolic acid and their copolymers, have some shortcomings compared to natural polymers, e.g. lack of natural binding sites and acidic products of degradation. However, they can still be used in a variety of scaffolds as well as combined with other polymers. The combination of hydrophilic polymers, e.g. chitosan or hyaluronic acid, and hydrophobic polymers, e.g. PCL or silk fibroin, had a positive effect on cell seeding and growth (Neves et al. 2011, Bhardwaj et al. 2011, Lebourg et al. 2014). Additionally, other techniques were tested to increase the hydrophilicity of PCL; oxygen plasma treatment and/or alkaline hydrolysis showed a positive effect on chondrocyte differentiation and cartilaginous tissue formation (Uppanan et al. 2015). However, the ideal scaffold, combining good cell proliferation and differentiation along with viscoelastic properties similar to native cartilage, has to be developed.

Composite hydrogel or foam scaffolds with incorporated microfibers are reported to show increased biomechanical properties (Prosecká et al. 2015, Filová et al. 2013). We have studied porous scaffolds with 10 or $15 \mathrm{wt} \%$ PCL containing 0,10 or $20 \mathrm{wt} \%$ chitosan microparticles. We hypothesized that our composite scaffolds would exhibit improved viscoelastic properties in dynamic tests as well as support chondrocyte proliferation and differentiation in in vitro tests; the aim of our work was to find an optimal system for cartilage regeneration.

\section{Methods}

\section{Scaffold preparation}

Chitosan fibres of $20-\mu \mathrm{m}$ diameter were obtained from Weifang Youngdeok Chitosan Co. Ltd. (China). They were ground using a CryoMill (Retsch $\mathrm{GmbH}$, Germany) for $30 \mathrm{~s}$ twice, using a frequency of $25 \mathrm{MHz}$ at $-80{ }^{\circ} \mathrm{C}$. Chitosan microparticles were then sieved using a sieve with $40-\mu \mathrm{m}$ pores (amplitude 60, $10 \mathrm{~min}$, shaker AS 200 Retsch, Severn Sales, UK). PCL was purchased from Sigma-Aldrich (Cat. No.704105, $\mathrm{M}_{\mathrm{w}}=40,000-50,000$ ). The salt leaching technique was used for the preparation of the foam scaffolds. PCL (10 wt $\%$ or $15 \mathrm{wt} \%$ ) was dissolved in a mixture of $99 \%$ chloroform-100\% ethanol $(9: 1 \mathrm{w} / \mathrm{w}$, cat. nos. 25692 and 02862, respectively, both from Penta,
Czech Republic). $\mathrm{NaCl}$ (ChemPro) was sieved using a sieve with $400-\mu \mathrm{m}$ pores; the fraction sieved was used as a porogen and mixed with the PCL solution by sonication. Pure PCL samples (PCL10_CH0, PCL15_CH0) or samples with 10 or $15 \mathrm{wt} \%$ of chitosan microparticles were prepared (e.g. for $10 \mathrm{wt} \%$ PCL-PCL10_CH10 and PCL10_CH20) (Table 1) and subsequently dried in a desiccator for 4 days. Then, the samples were washed in distilled water for $24 \mathrm{~h}$ to dissolve the porogen, tested for conductivity and dried for 2 days at room temperature (RT).

Table 1. Scaffold composition; scaffolds were prepared either from 10 or $15 \mathrm{wt} \%$ poly- $\varepsilon$-caprolactone (PCL) solution and contain 0,10 or $20 \mathrm{wt} \%$ chitosan microparticles.

\begin{tabular}{lcc}
\hline Scaffold & $\begin{array}{c}\text { PCL solution } \\
(\mathbf{w t} \%)\end{array}$ & $\begin{array}{c}\text { Amount of } \\
\text { chitosan (wt\%) }\end{array}$ \\
\hline PCL10_CH0 & 10 & 0 \\
PCL10_CH10 & 10 & 10 \\
PCL10_CH20 & 10 & 20 \\
PCL15_CH0 & 15 & 0 \\
PCL15_CH10 & 15 & 10 \\
PCL15_CH20 & 15 & 20 \\
\hline
\end{tabular}

\section{Scaffold characterization}

Characterization of chitosan microparticles was performed using scanning electron microscopy (SEM) and subsequent analysis of the SEM micrographs using LUCIA G software for image analysis.

Scaffolds were visualized on a confocal microscope Zeiss LSM 5 DUO using DiOC6(3) staining at excitation wavelength, $\lambda_{\text {exc }}=488 \mathrm{~nm}$ and emission wavelength, $\lambda_{\mathrm{em}}=505-550 \mathrm{~nm}$.

\section{Scaffold seeding}

Foam scaffolds were cut into small cylinders with a diameter of $6 \mathrm{~mm}$. We removed the air from the samples with a syringe under negative pressure (Pamula et al. 2009) using phosphate buffer saline (PBS). Each scaffold was seeded with $45 \times 10^{3}$ primary pig-chondrocytes and grown in Iscove's Modified Dulbecco's Medium (Sigma; Cat: 13390), supplemented with $12 \%$ fetal bovine serum, $100 \mathrm{IU} / \mathrm{ml}$ and $100 \mu \mathrm{g} / \mathrm{ml}$ penicilin/streptomycin (PAA; Cat: P11-010), $400 \mathrm{mM}$ L-glutamine (Gibco; Cat: 25030), $10 \mu \mathrm{g} / \mathrm{ml}$ insulin, $5.5 \mathrm{mg} / \mathrm{l}$ transferrin, $6.7 \mu \mathrm{g} / \mathrm{l}$ sodium selenium, $2 \mathrm{mg} / \mathrm{l}$ ethanolamine (ITS-X, Gibco; Cat. No. 51500-056), 
$100 \mathrm{nM}$ dexamethasone and $20 \mu \mathrm{l} / \mathrm{ml}$ ascorbate-2phosphate (Sigma; Cat: A8960), in a humidified atmosphere at $37{ }^{\circ} \mathrm{C}$ and $5 \% \mathrm{CO}_{2}$ for 7,14 and 22 days.

\section{Cell viability evaluation}

Cell viability was evaluated using CellTiter $96^{\circledR}$ AQueous One Solution Cell Proliferation Assay (MTS, Promega). Samples were incubated in $100 \mu 1$ medium and $20 \mu \mathrm{l}$ MTS solution containing 3-(4,5-dimethylthiazol-2yl)-5-(3-carboxymethoxyphenyl)-2-(4-sulfophenyl)-2Htetrazolium and phenazine ethosulfate for $90 \mathrm{~min}$ in a $\mathrm{CO}_{2}$ incubator. The formazan formation was measured using a multi-mode spectrophotometer, Synergy HT (BioTek, USA), at $\lambda=490 \mathrm{~nm}$ and $\lambda_{\text {ref }}=690 \mathrm{~nm}$. Cell viability was evaluated in 2 independent experiments using 3-4 samples per foam-type on days 1, 7, 14 and 22 of the study.

\section{Cell proliferation assay}

Cell proliferation was evaluated using Quant-iT ${ }^{\mathrm{TM}}$ PicoGreen ${ }^{\circledR}$ dsDNA Assay Kit (Life Technologies) and cell lysates containing $0.2 \%$ Triton, $10 \mathrm{mM}$ TRIS and $1 \mathrm{mM}$ EDTA. Fluorescence was measured at $\lambda_{\text {exc }}=502 \mathrm{~nm}$ and $\lambda_{\text {em }}=523 \mathrm{~nm}$. The dsDNA assay was evaluated in 2 independent experiments using 3-4 samples/foam type on days $1,7,14$ and 22 of the study.

\section{Cell visualization}

The cells on scaffolds were fixed by frozen methanol $\left(-20^{\circ} \mathrm{C}\right)$. Before staining, the scaffolds were washed twice with PBS. Cell membranes were stained with $1 \mu \mathrm{g} / \mathrm{ml}$ of 3,3'-dihexyloxacarbocyanine iodide (DiOC6(3) (Cat. No. D273, Invitrogen) for $45 \mathrm{~min}$ and the cell nuclei were stained with propidium iodide. The cells were visualized under a confocal microscope, Zeiss LSM 5 DUO, $\lambda_{\text {exc }}=488 \mathrm{~nm}, \lambda_{\text {em }}=505-550 \mathrm{~nm}$ for DiOC6(3) and $\lambda_{\text {exc }}=560 \mathrm{~nm}, \lambda_{\mathrm{em}}=575-620 \mathrm{~nm}$ for propidium iodide.

\section{Collagen visualization}

For type II collagen visualization, samples were incubated in $3 \%$ fetal bovine serum in $\mathrm{PBS} / 0.1 \%$ Triton X-100 at RT for $30 \mathrm{~min}$. Then, we performed immunohistochemical staining using monoclonal antibody against type II collagen (diluted 1:20, incubated overnight at $2-8^{\circ} \mathrm{C}$ ). The monoclonal antibody, clone II-II6B3 was obtained from the Developmental Studies Hybridoma Bank, created by the NICHD of the NIH and maintained at the Department of Biology, University of
Iowa, Iowa City, IA 52242. After three washes with PBS $/ 0.05 \%$ Tween 20 , the secondary goat anti-mouse antibody conjugated with Alexa Fluor 488® (Life Technologies, USA, dilution 1:300) was added for $45 \mathrm{~min}$ at RT. Scaffolds were subsequently stained with $5 \mu \mathrm{g} / \mathrm{ml}$ propidium iodide for $8 \mathrm{~min}$ and washed with PBS.

Both type II collagen and second harmonic generation (SHG) signals were visualized using Leica TCS SP2 acousto-optical beamsplitter (AOBS) multiphoton (MP) confocal laser scanning microscope using one-photon imaging for type II collagen and SHG imaging, as reported previously (Filová et al. 2010). In short, for SHG detection, we used a photomultiplier for non-descanned detection of SHG signal in the backward mode, where the signal was collected directly behind the object by a photomultiplier. For the detection of type II collagen, $\lambda_{\text {exc }}=488 \mathrm{~nm}, \lambda_{\text {em }}=505-550 \mathrm{~nm}$ and for the detection of SGH signal, $\lambda_{\text {exc }}=860 \mathrm{~nm}, \lambda_{\text {em }}=420-440 \mathrm{~nm}$ were used. For cell visualization, settings similar to those used for the Carl Zeiss LSM 510 DUO were used. The Leica SP2 AOBS MP microscope was set to $\lambda_{\text {exc }}=488 \mathrm{~nm}$ and $\lambda_{\mathrm{em}}=505-532 \mathrm{~nm}$ for DiOC6(3), and $\lambda_{\text {exc }}=543 \mathrm{~nm}$ and $\lambda_{\mathrm{em}}=626-662 \mathrm{~nm}$ for propidium iodide. The scaffolds were scanned using the same settings: $70-90-\mu \mathrm{m}$-thick $\mathrm{z}$-stack of images at $10 \times$ objective, or 5 - $\mu \mathrm{m}$-thick $\mathrm{z}$-stack of images at $63 \times$ objective.

\section{Scaffold evaluation}

The area of collagen or SHG signal was measured by marking the collagen signal on a grid with an automatic measurement of the collagen/SHG signal positive area and calculating the area per cell. Six to eight pictures for each tested group were evaluated. Autofluorescence of the pure scaffold was not taken into account.

\section{Biomechanical evaluation}

The viscoelastic properties are characterized by the storage and loss moduli (Chanda and Roy 2007). The storage modulus represents the ability to store energy and is calculated from storage stiffness. The loss modulus $\left(\mathrm{E}_{\text {loss }}\right)$ characterizes the ability to dissipate energy and is calculated from loss stiffness (Chanda and Roy 2007).

The dynamic measurements are performed using previously reported apparatus (Fig. 1) (Kuchařová et al. 2007, Doubal et al. 2009). Briefly, the measurement is based on the resonance method. The lower end of the sample is connected to the frame (bottom fixation), and the upper end of the sample is connected to a weight, 
which is connected to the lower end of a calibrated spring. The upper part of the spring is connected with a firm frame using a micrometer screw. The system of spring-weight-sample forms a mechanical oscillator that oscillates by damped oscillations after the short energy impulse. On the basis of the oscillation frequency and the damping coefficient, we can calculate the real and imaginary part of the complex modulus of the sample. The micrometer screw enables to adjust the mechanical static preloading of the sample.

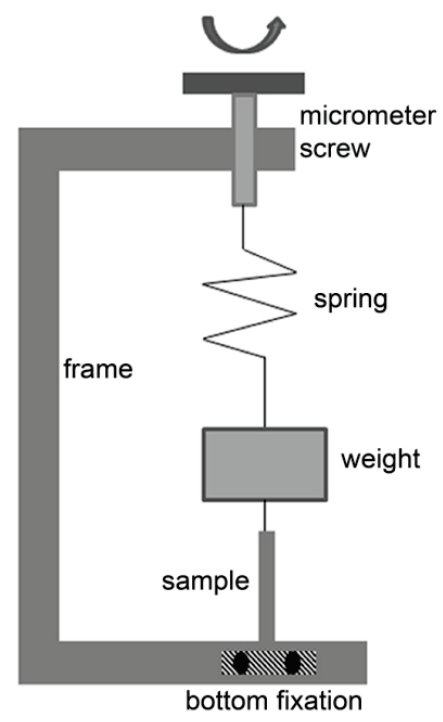

Fig. 1. Apparatus for the dynamic measurement of viscoelastic properties of poly- $\varepsilon$-caprolactone/chitosan foams.

The principle of measurement is based on measurement of self-oscillation of system sample-inertial body (attached weight). For self-oscillation it holds, that:

$$
L(t)=L_{0} e^{-k . t} \cdot \sin (\omega . t)
$$

where $\mathrm{L}$ is the deformation. Supposing the behavior of the sample obeys the Voigt model, the Newton coefficient $(\mathrm{N})$ is:

$$
N=2 M k
$$

where $\mathrm{M}$ is the mass of the inertial body. Hooke's coefficient is:

$$
H=M \omega^{2}+\frac{N^{2}}{4 M}
$$

The storage modulus $\left(\mathrm{E}_{\mathrm{D}}\right)$ is thus:

$$
E_{\mathrm{D}}=H \frac{l}{A}
$$

where 1 is the length of the sample and $A$ is the cross sectional area of the sample. The loss modulus $\left(\mathrm{E}_{\text {loss }}\right)$ is thus:

$$
E_{\text {loss }}=N \frac{l}{A}
$$

\section{Statistical analysis}

The data are presented as mean and standard deviation. For the statistical analysis we used software SigmaStat 12.0 (Systat Software Inc., San Jose, California) and One Way Analysis of Variance (ANOVA) and Student-Newman-Keuls Method. For the evaluation of the results from the SHG pictures, we used the nonparametric Kruskal-Wallis One Way Analysis of Variance on Ranks. The level of significance was set at 0.05 .

\section{Results}

Chitosan-functionalized PCL foam showed high regularity of the foam structure

We prepared foams from 10 or $15 \mathrm{wt} \% \mathrm{PCL}$ containing 0,10 , and $20 \mathrm{wt} \%$ chitosan microparticles. Scaffolds prepared by salt-leaching techniques exhibited porous structures with open pores that enabled cell growth and good diffusion of nutrition (Fig. 2A-F). The size of the chitosan microparticles was assessed from the SEM images. The area of the prepared chitosan microparticles was $653 \pm 430 \mu \mathrm{m}^{2}$ (mean and standard deviation) and the area-equivalent diameter was $27.4 \pm 9.1 \mu \mathrm{m}$. SEM micrographs of chitosan microspheres are shown in Fig. 2G-I. SEM of pure PCL scaffolds (Fig. 2H) showed a smooth surface. PCL with chitosan microparticles showed a rough surface with sharp chitosan microparticles protruding from the surface (Fig. 2I). The PCL10_CH0 scaffolds have a structure corresponding to the size of $\mathrm{NaCl}$ pores, only the pores were bigger and irregular. The addition of chitosan into PCL led to a more regular structure (Fig. 2).

Both cell viability and DNA content were high in PCL scaffolds with low amounts of chitosan

The cell viability assay showed significantly higher absorbance of formazan salt on the two pure PCL scaffolds (e.g. PCL10_CH0, PCL15_CH0) than on all chitosan-modified scaffolds on day 1 (Fig. 3). The same observation was seen on PCL10_CH0 on day 14. On the other hand, $15 \mathrm{wt} \%$ PCL scaffolds showed higher absorbance than PCL10_CH10 on day 1. The lowest cell viability was observed in PCL15_CH20 scaffold. The cell viability assay is in accordance with the results from the DNA assay. 


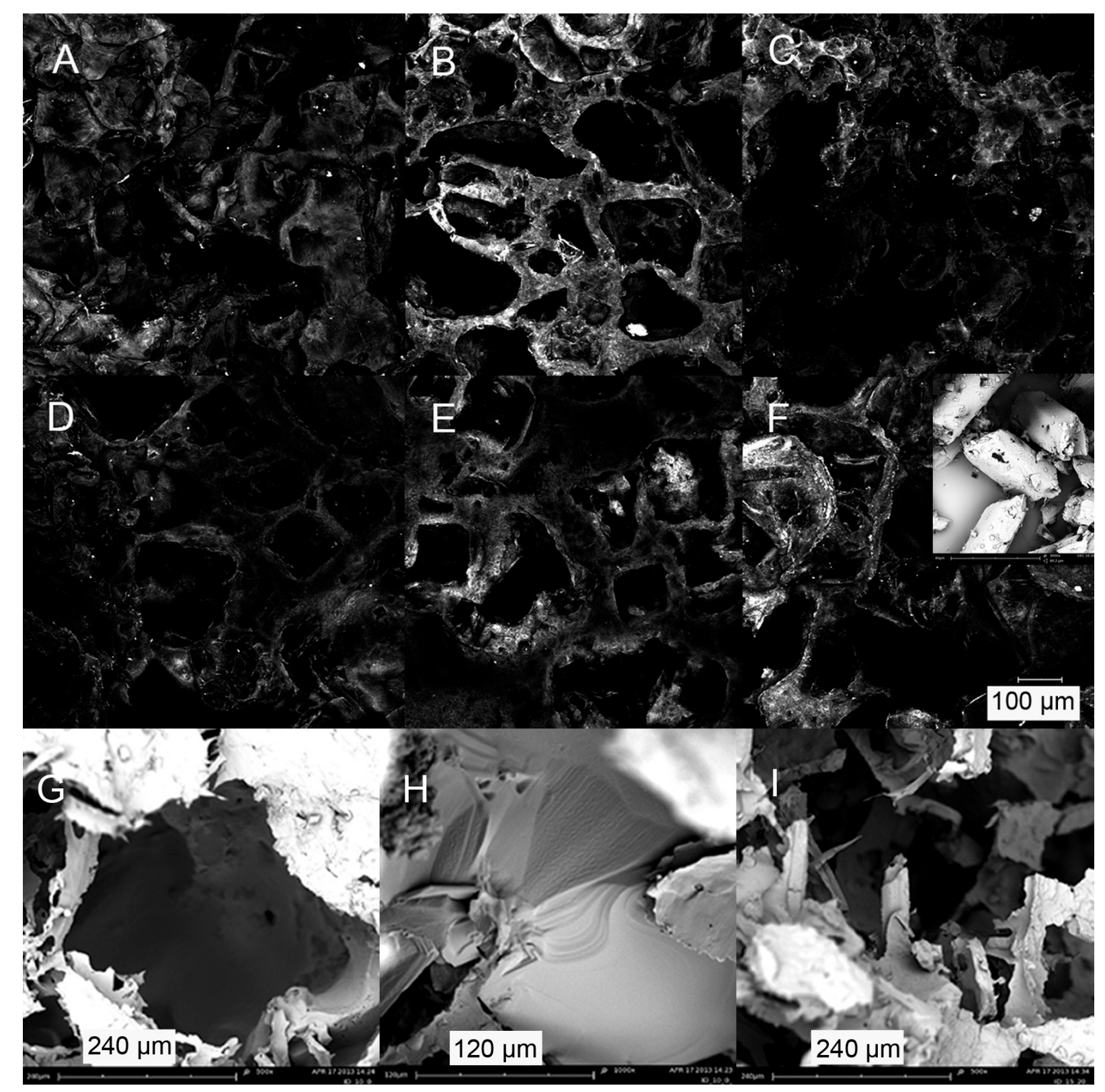

Fig. 2. Confocal microscope photomicrographs (A-F) of unseeded poly- $\varepsilon$-caprolactone/chitosan $(P C L$ _CH) foam scaffolds with different concentrations of both components (wt\%) stained with DiOC6 and scanned using confocal microscope Zeiss LSM 5 Duo showed open, interconnected pores and scanning electron microscopy pictures (SEM) of the scaffolds. (A) PCL10_CH0, (B) PCL10_CH10, (C) PCL10_CH20, (D) PCL15_CH0, (E) PCL15_CH10, (F) PCL15_CH20 with SEM picture of chitosan microspheres, bar=40 $\mu \mathrm{m}$. Objective $\times 10$, maximum projection from the 150-250 $\mu$ m-thick z-stacks. (G-H) PCL10_CH0 scaffolds with smooth surface, (I) PCL15_CH20 scaffolds with rough surface with chitosan microparticles.

Pure $10 \mathrm{wt} \%$ PCL scaffold (PCL10_CH0) showed the highest DNA content during the entire growth period. The scaffolds with no chitosan and $10 \mathrm{wt} \%$ chitosan showed higher DNA content than both scaffolds with $20 \mathrm{wt} \%$ chitosan on day 7 . On day 22, the lowest DNA content was seen on PCL15_CH20 scaffold (Fig. 3B). The chondrocytes adhered well to all foam scaffolds. On day 22, confluent cell layers were observed on all scaffolds (Fig. 4).
Collagen visualized using SHG imaging did not differ among samples

The total collagen content in the extracellular matrix has been assessed by SHG imaging. The imaging technique, as described previously, is a quick and modern non-invasive technique for detection of the total collagen amount in the scaffold, including type I and type II. A low SHG signal was detected in all scaffolds. The area of SHG per cell indicates the total collagen amount; it did not differ significantly during the entire growth period. 

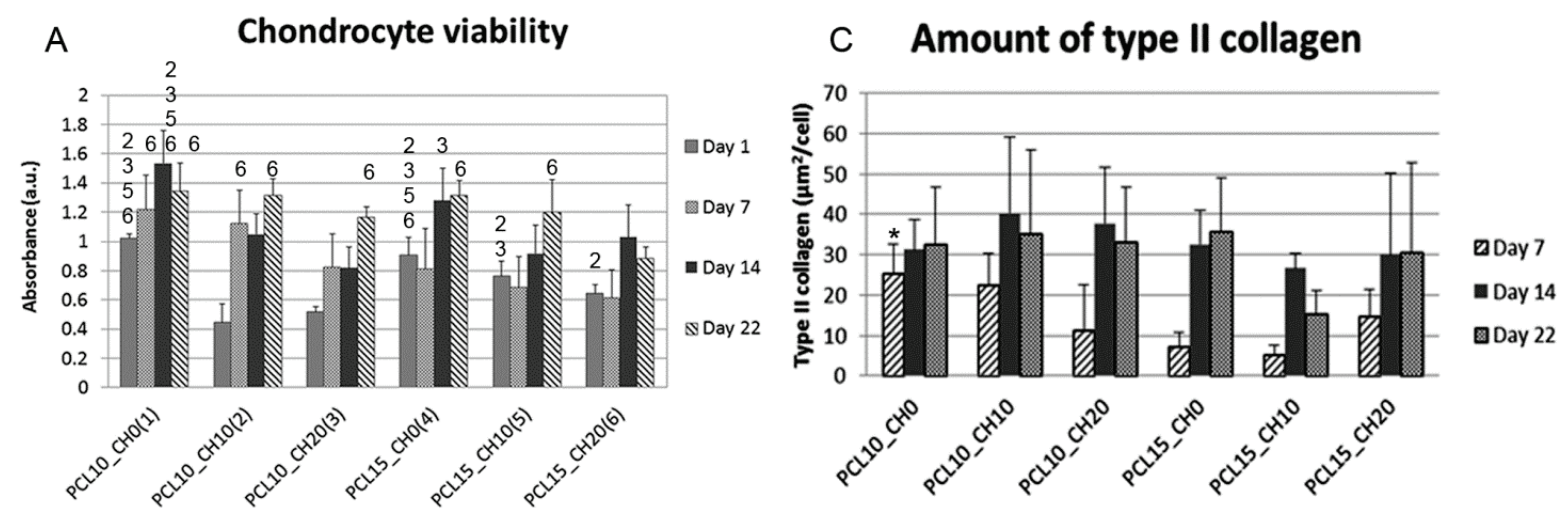

B

DNA assay

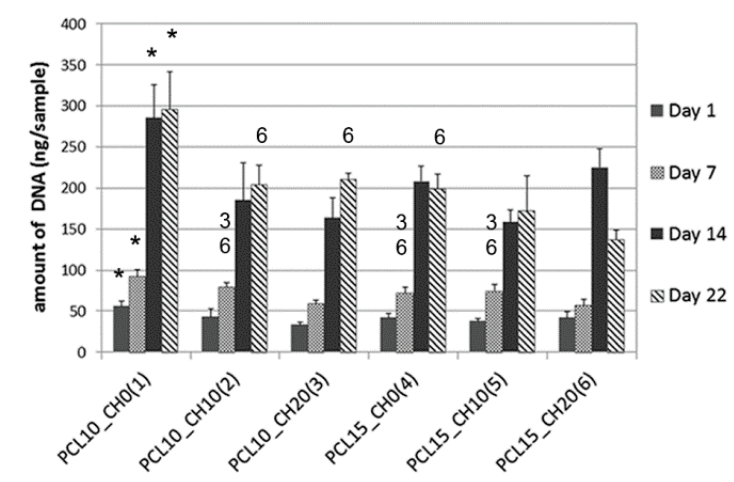

Fig. 3. Cell viability assay (MTS) (A), DNA assay (B), type II collagen synthesis (C) on chondrocyte-seeded poly- $\varepsilon$-caprolactone/ chitosan foam scaffolds with different ratio of PCL and chitosan (wt\%). The statistical differences among samples are shown above the columns. * denotes a significantly higher value compared to other samples.

Amount of type II collagen was higher in $10 \mathrm{wt} \% \mathrm{PCL}$ scaffolds with low amount of chitosan than in other samples

Immunohistochemistry was used to specifically detect type II collagen in the scaffolds. Type II collagen was observed mainly in the regions with a high density of chondrocytes (Fig. 4M,N). The amount of type II collagen per cell increased on day 14 in all scaffolds. On day 7, a higher amount of type II collagen was found in PCL10_CH0 compared to other scaffolds (Fig. 3C).

Chitosan-functionalized foams prepared from $10 \mathrm{wt} \%$ PCL showed improved viscoelastic properties

The influence of chitosan microparticles on the biomechanical properties of PCL foams was characterized. The stiffness was characterized by the storage modulus $\left(\mathrm{E}_{\mathrm{D}}\right)$. The storage modulus of $10 \mathrm{wt} \%$ PCL foams increased after the addition of chitosan (PCL10_CH10 and PCL10_CH20). However, no improvement was found in $15 \mathrm{wt} \%$ PCL samples (Fig. 5). Energy dissipation, which is a crucial point for cartilage function, was estimated from loss modulus $\left(\mathrm{E}_{\text {loss }}\right)$. Similar to the storage modulus, loss modulus was higher in PCL10_CH10 and PCL10_CH20 than in samples
PCL15_CH0 and PCL15_CH10.

\section{Discussion}

PCL foams with a low concentration of chitosan microparticles are suitable scaffolds for chondrocyte viability and proliferation

Both cell viability as well as cell proliferation was high in all the PCL foam scaffolds. However, PCL10_CH0 showed significantly higher cell viability, higher cell proliferation, and higher collagen synthesis than other scaffolds. There were no differences in cell proliferation between both scaffolds with $10 \mathrm{wt} \%$ chitosan and PCL15_CH0. The PCL15_CH20 scaffold was found to be less suitable for cell proliferation. Both PCL scaffolds with $20 \mathrm{wt} \%$ chitosan showed slower cell growth than both PCL scaffolds with 0 and $10 \mathrm{wt} \%$ chitosan on day 7. On day 22, PCL15_CH20 showed slower cell growth than other scaffolds except for PCL15_CH10. The increasing content of chitosan in the scaffold had a negative effect on chondrocyte proliferation. Pure $10 \mathrm{wt} \%$ PCL scaffolds showed the highest cell growth and viability as well as type II collagen synthesis (Fig. 3). 


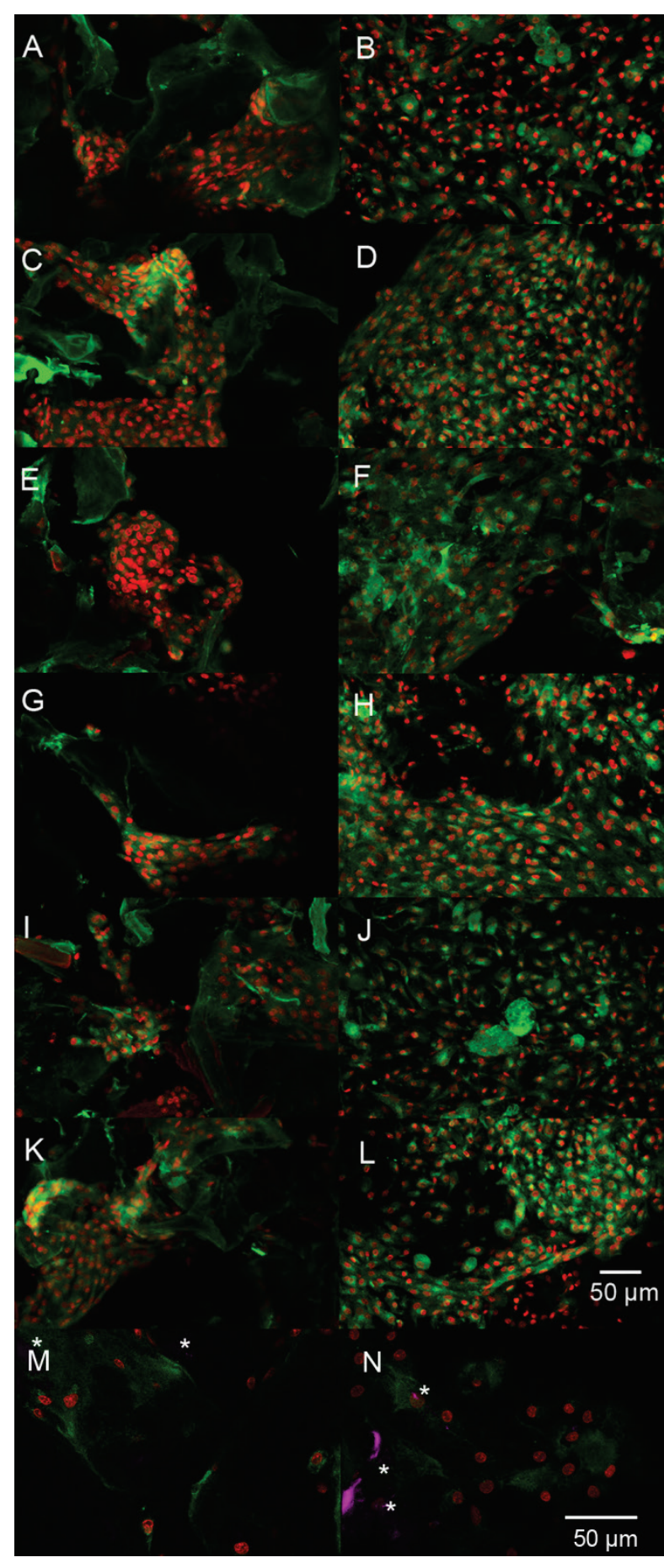

Fig. 4. Poly- $\varepsilon$-caprolactone/chitosan (PCL_CH) foam scaffolds (6-mm diameter) with different concentrations of both components (wt\%) seeded with $45 \times 10^{3}$ chondrocytes showed good cell adhesion on day $1(\mathbf{A}, \mathbf{C}, \mathbf{E}, \mathbf{G}, \mathbf{I}, \mathbf{K})$ and a nearly confluent cell layer on the surface of pores in all scaffolds on day 22 (B, $\mathbf{D}, \mathbf{F}, \mathbf{H}, \mathbf{J}, \mathbf{L})$ after seeding. DiOC6 (green) and propidium iodide (cell nuclei-red) staining scanned using confocal microscope Zeiss LSM 5 Duo. A,B - PCL10_CHO, C,D PCL10_CH10, E,F - PCL10_CH20, G,H - PCL15_CH0, I,J PCL15_CH10, K,L - PCL15_CH20. Objective $\times 20 . \mathbf{M}, \mathbf{N}-$ type II collagen (green) and cell nuclei (red) (M) and second harmonic generation signal of collagen (N) on PCL10_CH0 scaffold 7 days (M) and 22 days $(\mathbf{N})$ after seeding of chondrocytes. * denotes the SHG signal near chondrocytes. Maximum projection of the $5 \mu \mathrm{m}$-thick z-stack, objective $\times 63$, bar $=50 \mu \mathrm{m}$.

\section{Storage modulus $E_{D}$}

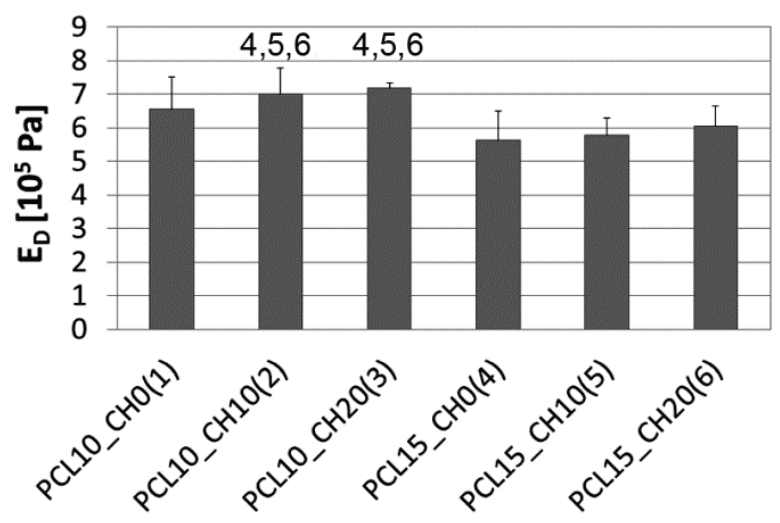

\section{Loss Modulus $\mathrm{E}_{\text {Loss }}$}

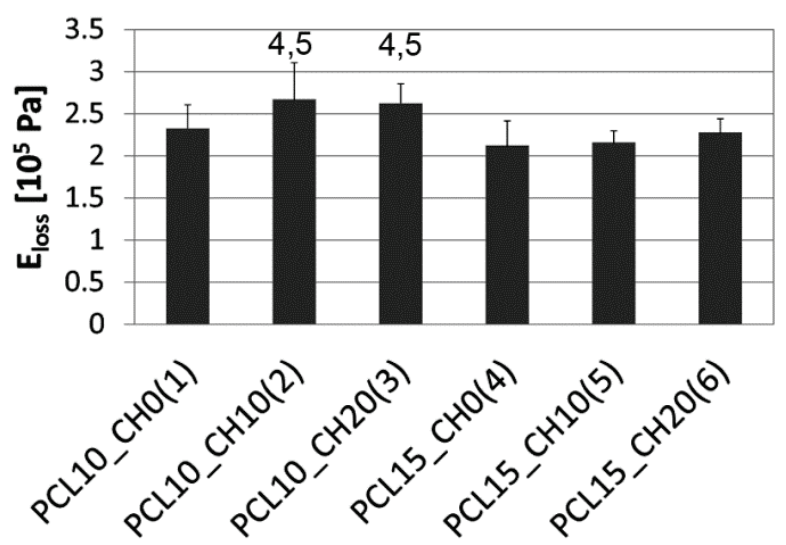

Fig. 5. Dynamic evaluation of dry PCLCHIT scaffolds showed significantly higher storage modulus $\mathrm{E}_{\mathrm{D}}$ in PCL10_CH10 and PCL10_CH20 foams compared with all foam with 15 wt\% PCL foams (e.g. samples 4-6). Loss modulus $E_{\text {loss }}$ of PCL10_CH10 and PCL10_CH20 was significantly higher than $E_{\text {loss }}$ in PCL15_CH10 and PCL15_CH20 foams.

The differences in cell growth rate and viability may be caused by higher porosity of pure $10 \mathrm{wt} \% \mathrm{PCL}$ scaffolds, which is in accordance with the observations made by Pamula et al. (2009).

\section{Chitosan microparticles modified PCL foam structure}

Our $10 \mathrm{wt} \%$ PCL scaffold showed an irregular structure with larger pores. The area equivalent pore diameter in our scaffolds was $120-150 \mu \mathrm{m}$. The structure of other scaffolds was similar because the same porogen $(\mathrm{NaCl})$, in the same amounts, was used during preparation.

It is hypothesized that larger pores contribute to improved cell adhesion, viability, and proliferation under dynamic conditions and in in vivo study. This is in 
accordance with other reports of improved chondrocyte adhesion and viability in the PCL/nano-hydroxyapatite foam scaffold containing the highest ratio of pores of diameter above $100 \mu \mathrm{m}$ than in scaffolds with smaller pores (Liu et al. 2012). Similarly, the penetration of cells into a poly(L-lactide-co-glycolide) scaffold with the same porosity and large pore diameter was significantly higher than that in a scaffold with smaller pore diameter. The scaffolds with large pores exhibited higher cell proliferation during the first week of culture under static conditions compared to those with small pores (Pamula et al. 2009). As our samples were cultured under static conditions, the influence of pore size on cell proliferation was limited owing to the lower diffusion inside the scaffold.

Cell-biomaterial interactions are complex; cells adhere on the surface of the scaffold through focal adhesions formed by transmembrane and extracellular proteins, including integrin receptors, and proteoglycan and actin cytoskeleton. After contact of the scaffold with the medium or plasma, rapid adsorption of the proteins onto the scaffold occurs. The composition of the protein layer plays a key role in cell behavior; for example, osteoblast cells increase their attachment on the surfaces in the presence of vitronectin or fibronectin (Wilson et al. 2005). Protein adsorption is influenced by the chemistry, charge, and free energy of the surface (von Recum and van Kooten 1995). More proteins were found to adsorb onto hydrophobic than on hydrophilic surfaces. However, improved cell adhesion was shown on charged, hydrophilic surfaces (Wilson et al. 2005). Osteoblasts showed improved adhesion on cationic surfaces (Shelton et al. 1988). The cell growth, proliferation, and differentiation are also affected by different surface roughness (von Recum and van Kooten 1995, Lincks et al. 1998).

Chitosan porous scaffolds showed lesser cell adhesion than scaffolds fabricated from polyglycolic acid after dynamic seeding and culture for 48 days. In addition, chitosan scaffolds with pore diameters of 70-120 $\mu \mathrm{m}$ showed better chondrocyte proliferation than scaffolds with smaller pores, but non-woven scaffolds from polyglycolic acid showed 6-times higher DNA content than chitosan scaffolds with larger pores, 28 days after the seeding (Griffon et al. 2006). Conversely, chitosan hydrogel stimulated glycosaminoglycan synthesis similar to alginate hydrogel, but stimulated type II collagen synthesis more than alginate and fibrin hydrogels (Sheehy et al. 2015). In our experiment,
$15 \mathrm{wt} \%$ PCL scaffolds showed higher absorbance in cell viability assay on day 1 compared to both the $15 \mathrm{wt} \%$ scaffolds with chitosan.

Neves et al. (2011) prepared a blend of nanofibres from PCL and chitosan in different ratios. Blends with $75 / 25$ and $50 / 50 \mathrm{w} / \mathrm{w}$ ratios showed better cell distribution and growth than pure chitosan scaffolds, which showed a rougher surface on which the cell were aggregated and not homogeneously distributed (Neves $e t$ al. 2011). In both the blends, chondrocytes proliferated till day 14 , but fewer cells were found in the $50 / 50$ blend then in the $75 / 25$ blend. The pure chitosan scaffold showed the lowest cell proliferation. We observed homogeneous cell distribution in all our scaffolds, but the cells were localized in the upper part due to static cultivation.

PCL foam functionalized with a low amount of chitosan microparticles triggers type II collagen production and improves energy dissipation

Collagen is the most abundant component of the extracellular matrix of tissues and plays an important role in tissue structure, organization, and function. The SHG signal includes all collagens that are able to provide SHG signal with different intensities. Type I collagen forms fibres that provide a strong signal in tissues, e.g. in skin (Wu et al. 2015), bone (Sepitka et al. 2012), tendon (Shen et al. 2013) and arteries (Cicchi et al. 2014). On the other hand, types II, III, IV and V provide low SHG signal. Type II collagen, which is present in cartilage, does not form fibres and thus provides a faint, more homogeneous signal (Filova et al. 2010, Brown et al. 2013, Lutz et al. 2012). SHG enables the quantitative analysis of morphological changes in altered tissues, such as in dermatofibrosarcoma protuberans skin (Wu et al. 2015) or in osteoarthritis (Brown et al. 2012). In our samples, pure PCL scaffolds and chitosan microparticles also provided a SHG signal. The total area of the collagen SHG signal was similar in our samples. We have observed both type II and type I collagen signals in the scaffolds, which is typical for fibrocartilage (Fig. 4M,N). Type II collagen formation was found near chondrocytes (Fig. 4M,N). This is in agreement with the faster type II collagen formation in our PCL10_CH0 sample compared to other samples on day 7. The increased synthesis of type II collagen shows that more cartilaginous tissue was formed in $10 \mathrm{wt} \%$ PCL samples with a low amount of chitosan compared to other samples.

Higher contents of type II collagen could be 
related to tissue function. Clearly, cartilage is a specific viscoelastic tissue with effective energy dissipation and damping properties. The viscoelastic properties were characterized by storage and loss moduli (Chanda and Roy 2007). Storage modulus (elastic response) represents the ability to store energy and is calculated from storage stiffness and $\mathrm{E}_{\mathrm{loss}}$ characterizes the ability to dissipate energy and is calculated from loss stiffness (Chanda and Roy 2007, Fulcher et al. 2009). Viscoelastic properties are important for the implantation of scaffolds into the load-bearing parts of knee cartilage as they also may influence cell survival during mechanical loading and cell differentiation, and subsequent healing of the cartilage defects. Both the moduli in our PCL scaffolds significantly increased in both the chitosan-modified $10 \mathrm{wt} \%$ PCL scaffolds compared to the $15 \mathrm{wt} \%$ PCL scaffolds (Fig. 5). This is in accordance with our previous experiments, in which the addition of polyvinylalcohol nanofibers with liposomes into a hyaluronate/collagen/ fibrin hydrogel also led to improved biomechanical properties (Filová et al. 2013). In another experiment, PCL nanofibers cut into small particles improved the compressive elasticity modulus of the collagenhydroxyapatite foams (Prosecká et al. 2015).

From the biomechanical viewpoint, PCL10_CH10 and PCL10_CH20 showed improved stiffness and $E_{\text {loss, }}$ and are more suitable for cartilage repair than similar scaffolds with a higher amount of PCL. Both the moduli of our non-seeded scaffolds were significantly lower than those in bovine articular cartilage, where the storage modulus was calculated to be about $70 \mathrm{MPa}$ and $\mathrm{E}_{\text {loss }}$ to be about $5 \mathrm{MPa}$ (Fulcher et al. 2009). However, we have biomechanically tested dry scaffolds. Clearly, chondrocytes seeded on the scaffolds produce extracellular matrix that naturally leads to improvement of the viscoelastic properties of the repaired tissue (Bhardwaj et al. 2011). Similar observations were reported by Neves et al. (2011). Blends of porous PCL/chitosan scaffolds with increasing PCL concentration exhibited higher Young's modulus and decreased swelling. Malheiro et al. (2010) prepared blended fibre scaffolds from PCL/chitosan by wet spinning. The highest $E_{\text {loss}}$, representing energy dissipation, was found in the 75/25 (w/w) PCL/chitosan scaffold. Conversely, storage modulus, representing the stiffness, was proportional to chitosan content up to 5.2 GPa for pure chitosan scaffolds because of the interchain hydrogen bonding (Malheiro et al. 2010).

\section{Conclusions}

The best cell viability and proliferation as well as faster collagen formation was observed in pure $10 \mathrm{wt} \%$ PCL scaffolds. $10 \mathrm{wt} \%$ PCL scaffolds functionalized with low amounts of chitosan showed suitable cell growth, cell viability and production of type II collagen, which was accompanied by significant improvement in both the storage and the loss moduli. $10 \mathrm{wt} \%$ PCL scaffolds with $0 \mathrm{wt} \%$ or $10 \mathrm{wt} \%$ chitosan have a highly promising potential for cartilage tissue engineering.

\section{Conflict of Interest}

There is no conflict of interest.

\section{Acknowledgements}

The authors would like to thank Prof. RNDr. Ing. Stanislav Ďoubal, CSc., for biomechanical measurements and Daniel Hadraba, MSc. and Zuzana Burdíková, MSc., Ph.D. for assistance in confocal microscopy measurements. The grant was supported by the Internal Grant Agency of the Ministry of Health of the Czech Republic, project No. NT12156.

\footnotetext{
Abbreviations

DiOC6(3) - 3,3'-dihexyloxacarbocyanine iodide, PBS phosphate buffer saline, PCL - poly-E-caprolactone, PCL10_CH0 - scaffold prepared using $10 \mathrm{wt} \%$ PCL with $0 \mathrm{wt} \%$ chitosan microparticles, PCL10_CH20 - scaffold prepared using $10 \mathrm{wt} \%$ PCL with $20 \mathrm{wt} \%$ chitosan microparticles, $\mathrm{SHG}$ - second harmonic generation, $\mathrm{wt} \%$ - weight percent.
}

\section{References}

BHARDWAJ N, NGUYEN QT, CHEN AC, KAPLAN DL, SAH RL, KUNDU SC: Potential of 3-D tissue constructs engineered from bovine chondrocytes/silk fibroin-chitosan for in vitro cartilage tissue engineering. Biomaterials 32: 5773-5781, 2011.

BROWN CP, HOULE MA, CHEN M, PRICE AJ, LÉGARÉ F, GILL HS: Damage initiation and progression in the cartilage surface probed by nonlinear optical microscopy. J Mech Behav Biomed Mater 5: 62-70, 2012. 
BROWN CP, HOULE MA, POPOV K, NICKLAUS M, COUTURE CA, LALIBERTÉ M, BRABEC T, RUEDIGER A, CARR AJ, PRICE AJ, GILL HS, RAMUNNO L, LÉGARÉ F: Imaging and modeling collagen architecture from the nano to micro scale. Biomed Opt Express 5: 233-243, 2013.

CHANDA M, ROY SK: Plastics Technology Handbook. Fourth Edition. CRC Press, Boca Raton, 2007, pp 3-28 to 3-34.

CICCHI R, MATTHÄUS C, MEYER T, LATTERMANN A, DIETZEK B, BREHM BR, POPP J, PAVONE FS: Characterization of collagen and cholesterol deposition in atherosclerotic arterial tissue using non-linear microscopy. J Biophotonics 7: 135-143, 2014.

DI MARTINO A, SITTINGER M, RISBUD MV: Chitosan: a versatile biopolymer for orthopaedic tissue-engineering. Biomaterials 26: 5983-5990, 2005.

DOUBAL S, KLEMERA P, KUCHAROVA M, REJCHRT P: A new approach to measurement of viscoelastic parameters of biological structures. Proceedings of Second Fascia Research Congress. Vrije Universiteit, Amsterdam, 2009, p. 107.

FILOVA E, BURDIKOVA Z, RAMPICHOVA M, BIANCHINI P, CAPEK M, KOSTAKOVA E, AMLER E, KUBINOVA L: Analysis and three-dimensional visualization of collagen in artificial scaffolds using nonlinear microscopy techniques. J Biomed Opt 15: 066011, 2010.

FILOVÁ E, RAMPICHOVÁ M, LITVINEC A, DRŽÍK M, MíČKOVÁ A, BUZGO M, KOŠŤÁKOVÁ E, MARTINOVÁ L, USVALD D, PROSECKÁ E, UHLÍK J, MOTLÍK J, VAJNER L, AMLER E: A cell-free nanofiber composite scaffold regenerated osteochondral defects in miniature pigs. Int $J$ Pharm 447: 139-149, 2013.

FULCHER GR, HUKINS DWL, SHEPHERD DET: Viscoelastic properties of bovine articular cartilage attached to subchondral bone at high frequencies. BMC Musculoskelet Disord 10: 61, 2009.

GRIFFON DJ, SEDIGHI MR, SCHAEFFER DV, EURELL JA, JOHNSON AL: Chitosan scaffolds: interconnective pore size and cartilage engineering. Acta Biomater 2: 313-320, 2006.

HAO T, WEN N, CAO JK, WANG HB, LÜ SH, LIU T, LIN QX, DUAN CM, WANG CY: The support of matrix accumulation and the promotion of sheep articular cartilage defects repair in vivo by chitosan hydrogels. Osteoarthritis Cartilage 18: 257-265, 2010.

JEONG CG, ZHANG H, HOLLISTER SJ: Three-dimensional polycaprolactone scaffold-conjugated bone morphogenetic protein-2 promotes cartilage regeneration from primary chondrocytes in vitro and in vivo without accelerated endochondral ossification. J Biomed Mater Res A 100: 2088-2096, 2012.

KUCHAŘOVÁ, ĎOUBAL S, KLEMERA P, REJCHRT P, NAVRÁTIL M: Viscoelasticity of biological materials measurement and practical impact on biomedicine. Physiol Res 56: S33-S37, 2007.

LEBOURG M, MARTÍNEZ-DÍAZ S, GARCÍA-GIRALT N, TORRES-CLARAMUNT R, RIBELLES JL, VILACANET G, MONLLAU JC: Cell-free cartilage engineering approach using hyaluronic acid-polycaprolactone scaffolds: a study in vivo. J Biomater Appl 28: 1304-1315, 2014.

LINCKS J, BOYAN BD, BLANCHARD CR, LOHMANN CH, LIU Y, COCHRAN DL, DEAN DD, SCHWARTZ Z: Response of MG63 osteoblast-like cells to titanium and titanium alloy is dependent on surface roughness and composition. Biomaterials 19: 2219-2232, 1998.

LIU L, WANG Y, GUO S, WANG Z, WANG W: Porous polycaprolactone/nanohydroxyapatite tissue engineering scaffolds fabricated by combining $\mathrm{NaCl}$ and $\mathrm{PEG}$ as co-porogens: structure, property, and chondrocytescaffold interaction in vitro. J Biomed Mater Res B Appl Biomater 100: 956-966, 2012.

LUTZ V, SATTLER M, GALLINAT S, WENCK H, POERTNER R, FISCHER F: Characterization of fibrillar collagen types using multi-dimensional multiphoton laser scanning microscopy. Int J Cosmet Sci 34: 209-215, 2012.

MALHEIRO VN, CARIDADE SG, ALVES NM, MANO JF: New poly(epsilon-caprolactone)/chitosan blend fibers for tissue engineering applications. Acta Biomater 6: 418-428, 2010.

NEVES SC, MOREIRA TEIXEIRA LS, MORONI L, REIS RL, VAN BLITTERSWIJK CA, ALVES NM, KARPERIEN M, MANO JF: Chitosan/poly(e-caprolactone) blend scaffolds for cartilage repair: processing optimization. Biomaterials 32: 1068-1079, 2011. 
PAMULA E, FILOVÁ E, BACÁKOVÁ L, LISÁ V, ADAMCZYK D: Resorbable polymeric scaffolds for bone tissue engineering: the influence of their microstructure on the growth of human osteoblast-like MG 63 cells. $J$ Biomed Mater Res A 89: 432-443, 2009.

PROSECKÁ E, RAMPICHOVÁ M, LITVINEC A, TONAR Z, KRÁLÍČKOVÁ M, VOJTOVÁ L, KOCHOVÁ P, PLENCNER M, BUZGO M, MÍČKOVÁ A, JANČÁŘ J, AMLER E: Collagen/hydroxyapatite scaffold enriched with polycaprolactone nanofibers, thrombocyte-rich solution and mesenchymal stem cells promotes regeneration in large bone defect in vivo. J Biomed Mater Res A 103: 671-682, 2015.

PUPPI D, CHIELLINI F, PIRAS AM, CHIELLINI E: Polymeric materials for bone and cartilage repair. Prog Polym Sci 35: 403-440, 2010.

SAITO E, SUAREZ-GONZALEZ D, MURPHY WL, HOLLISTER SJ: Biomineral coating increases bone formation by ex vivo BMP-7 gene therapy in rapid prototyped poly(1-lactic acid) (PLLA) and poly( $\varepsilon$-caprolactone) (PCL) porous scaffolds. Adv Healthc Mater 4: 621-632, 2015.

SEPITKA J, LUKEŠ J, STANĚK L, FILOVÁ E, BURDÍKOVÁ Z, REZNÍČEK J: Nanoindentation of intervertebral disc tissues localised by SHG imaging. Comput Methods Biomech Biomed Engin 15 (Suppl 1): 335-336, 2012.

SHEEHY EJ, MESALLATI T, VINARDELL T, KELLY DJ: Engineering cartilage or endochondral bone: a comparison of different naturally derived hydrogels. Acta Biomater 13: 245-253, 2015.

SHELTON RM, RASMUSSEN AC, DAVIES JE: Protein adsorption at the interface between charged polymer substrata and migrating osteoblasts. Biomaterials 9: 24-29, 1988.

SHEN M, TIAN Y, CHONG SP, ZHAO J, ZENG H, TANG S: Quantifying the backscattering of second harmonic generation in tissues with confocal multiphoton microscopy. J Biomed Opt 18: 115003, 2013.

UPPANAN P, THAVORNYUTIKARN B, KOSORN W, KAEWKONG P, JANVIKUL W: Enhancement of chondrocyte proliferation, distribution, and functions within polycaprolactone scaffolds by surface treatments. J Biomed Mater Res A 103: 2322-2332, 2015.

VON RECUM AF, VAN KOOTEN TG: The influence of micro-topography on cellular response and the implications for silicone implants. J Biomater Sci Polym Ed 7: 181-198, 1995.

WILSON CJ, CLEGG RE, LEAVESLEY DI, PEARCY MJ: Mediation of biomaterial-cell interactions by adsorbed proteins: a review. Tissue Eng 11: 1-18, 2005.

WU S, HUANG Y, LI H, WANG Y, ZHANG X: Quantitative analysis on collagen of dermatofibrosarcoma protuberans. Scanning 37: 1-5, 2015. 